\title{
The eclipses in Livy's Ab Urbe Condita
}

\author{
Amelia Carolina Sparavigna \\ Politecnico di Torino
}

Titus Livius (Livy) is mentioning some eclipses in his monumental history of Rome, entitled Ab Urbe Condita Libri. For two of these eclipses, Livy is also reporting the dates. One occurred during the Ludi Apollinares, in the year of the consulship of Lucius Cornelius. Livy dated the eclipse 11 Quintilis. Astronomy dated it 14 March 190 BC (Julian date). The other eclipse is that at the time of the Pydna battle and it is the lunar eclipse of 21 June $168 \mathrm{BC}$ (Julian date). Livy tells that it occurred during the night between 3 and 4 September. The differences between astronomical and historical dates are due to the manner the lunisolar Roman republican calendar was managed in that period by the college of Roman pontifices. Here we discuss the eclipses reported by Livy to point out the problems of the Roman chronology, when it is involving the republican calendar.

Keywords: Archaeoastronomy, Chronology, CalSKY software, Stellarium software. Torino, 11 July 2019. DOI: 10.5281/zenodo.3330598

Titus Livius (Livy) was the Roman historian that wrote a monumental history of Rome - Ab Urbe Condita Libri - from the earliest legends to the reign of Augustus. In [1], it is told that Livy is reporting in his books some eclipses. In [1] we find the eclipses of sun occurring on 6 May $203 \mathrm{BC}$, 14 March 190 BC, and 17 July 188 BC, and the lunar eclipse of 21 June 168 BC (Julian dates). Of two of them, Livy is also reporting the dates according to the Roman republican calendar that he used. Here we show some details about these eclipses. In this manner, we have the occasion to discuss the Roman calendar and point out the related problem of Roman chronology. Let us add that another eclipse, which occurred in 217, is mentioned by Livy, but it is not considered in [1].

\section{The Republican Calendar}

Of the earliest calendar used by the Romans, we just know that it had 10 months, as indicated by the fact that our calendar ends in December. This calendar of the origins evolved into the calendar of the Republican times. Of this calendar, we have many documents and from them we can tell that it was not regular and roughly lunisolar. The monthly subdivisions, obtained by means of Kalends, Nones, and Ides, are showing a lunar origin. The months were beginning with the Kalends after the observation by priests of the new moon. The names of ten of the months were like those we use today. July was the Quintilis and August the Sextilis. The lengths of the months were of 29 and 31 days, with Februarius having 28 days. Consequently, a regular year had a total of 355 days. The year originally began in March.

To have the calendar in rough agreement to the seasons, a leap month, the Mercedonius, which was an intercalary February, was inserted at the end of February. The decision to intercalate a Mercedonius was taken by the pontifex maximus. This month was instituted, according to Roman tradition. by Numa Pompilius [2]. "It was supposed to be inserted every two or three years to align the conventional 355-day Roman year with the solar year" [3]. In practice, the college of Roman pontifices, which had to control the time, was quite inattentive to follow the rule, because the calendar was sometimes out of synchronization with the seasons of several months. For what concerns the years, the Latin writers mainly reckoned them by the means of the names of the consuls in office that year. This nanner to reckon the year persisted through the imperial period.

After this short discussion of the republican calendar, let us consdier the eclipses in Livy's text. 


\section{BC}

In the Liber XXX [4], we read the following: "Romae ad nuntium primum rebellionis Carthaginiensium trepidatum fuerat iussusque erat Ti. Claudius mature classem in Siciliam ducere atque inde in Africam traicere, et alter consul M. Seruilius ad urbem morari donec quo statu res in Africa essent sciretur. segniter omnia in comparanda deducendaque classe ab Ti. Claudio consule facta erant quod patres de pace Scipionis potius arbitrium esse quibus legibus daretur quam consulis censuerant. prodigia quoque nuntiata sub ipsam famam rebellionis attulerant terrorem: Cumis solis orbis minui uisus et pluit lapideo imbri, et in Ueliterno agro terra ingentibus cauernis consedit arboresque in profundum haustae; ... ; nam ita abundauit Tiberis ut ludi Apollinares circo inundato extra portam Collinam ad aedem Erycinae Ueneris parati sint. ceterum ludorum ipso die subita serenitate orta pompa duci coepta ad portam Collinam reuocata deductaque in circum est cum decessisse inde aquam nuntiatum esset; laetitiamque populo et ludis celebritatem addidit sedes sua sollemni spectaculo reddita."

That is [5]: "At Rome alarm was excited at the first intelligence of the renewal of hostilities by the Carthaginians; and Tiberius Claudius was directed to conduct the fleet with speed into Sicily, and cross over from that place into Africa. The other consul, Marcus Servilius, was directed to stay at the city until the state of affairs in Africa was ascertained. Tiberius Claudius, the consul, proceeded slowly with everything connected with the equipment and sailing of the fleet, because the senate had decided that it should be left to Scipio, rather than to the consul, to determine the conditions on which the peace should be granted. The accounts also of prodigies, which arrived just at the time of the news of the revival of the war, had occasioned great alarm. At Cumae, the orb of the sun seemed diminished, and a shower of stones fell; and in the territory of Veliternum the earth sank in great chasms, and trees were swallowed up in the cavities. ... Amid these events an unusually great rising of the waters was converted into a prodigy; for the Tiber overflowed its banks to such a degree, that as the circus was under water, the Apollinarian games were got up near the temple of Venus Erycina, without the Colline gate. However, the weather suddenly clearing up on the very day of the celebration, the procession, which had begun to move at the Colline gate, was recalled and transferred to the circus, on its being known that the water had retired thence. The joy of the people and the attraction of the games were increased by the restoration of this solemn spectacle to its proper scene."

In [1], we find that the eclipse on 6 may 203 BC (Julian date), "est du 5 juin -203 républicain, si l'on identifie cette éclipse avec celle évoquée par Cicéron, De Republica, I, 16, 25". This Book, written by Cicero between 54 and $51 \mathrm{BC}$, was reporting a date in the roman calendar of Numa - that is - in the Roman republican calendar, before the reform decided by Julius Caesar [6].

As we did in [7], for the study of the lunar eclipse of Alexander, let us use software CalSKY, a webbased astronomical calculator, created by Arnold Barmettler, University of Zurich. Let us use Cuma (Bacoli) as location to observe the eclipse. We find that on 6 May 203 BC, we had a Partial Solar Eclipse, Saros-Number: 54, Obscuration $=37.070 \%$, Altitude $=37.4^{\circ}$, Azimuth $=257.3^{\circ} \mathrm{WSW}$, Duration of eclipse $=2 \mathrm{~h} 16 \mathrm{~m}, \mathrm{ET}-\mathrm{UT}=12809.7 \mathrm{sec}$. The software gives us also the possibility to have a graphical chart, here shown in the Figure 1.

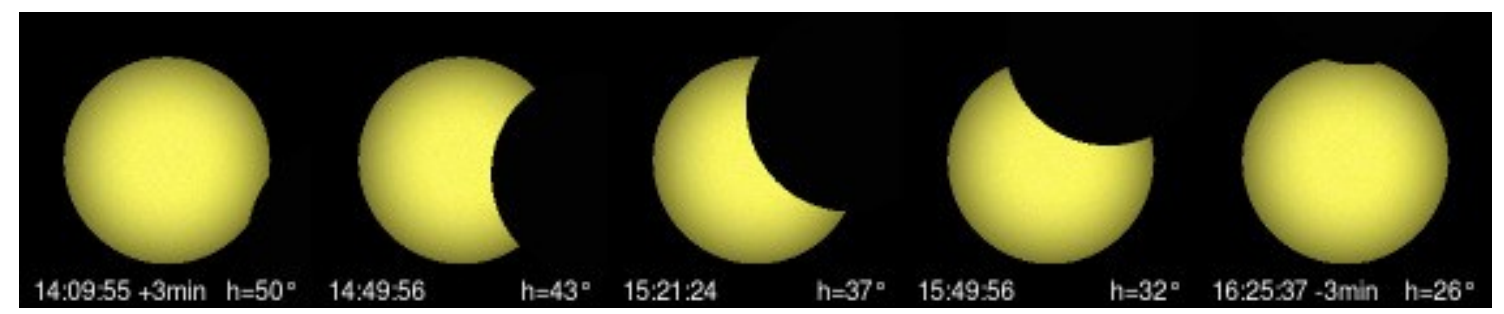

Figure 1: Courtesy CalSKY. Graphical chart of the partial eclipse of 203 BC seen from Cuma. "At Cumae the orb of the sun seemed diminished". 
As told by Livy, the eclipse happened at the same time that the news about the rebellion of the Carthaginians arrived in Rome. The eclipse was on 6 may 203 BC (Julian date), and the republican calendar gave 5 June 203 BC, according to Cicero. This seems to me quite good, because in Livy's text they are also mentioned the Ludi Apollinares. As we will discuss in the following, the Ludi were held in Quintilis (July). We can imagine that the "prodigia" mentioned by Livy occurred during the months of June and July of the republican calendar.

\section{$190 \mathrm{BC}$}

In the text, in Liber XXXVII, we can find mentioned another solar eclipse [8-10].

It is told that "L. Cornelius consul peractis, quae Romae agenda erant, pro contione edixit, ut milites, quos ipse in supplementum scripsisset, quique in Bruttiis cum A. Cornelio propraetore essent, ut hi omnes idibus Quinctilibus Brundisium conuenirent. item tres legatos nominauit, Sex. Digitium L. Apustium C. Fabricium Luscinum, qui ex ora maritima undique nauis Brundisium contraherent; et omnibus iam paratis paludatus ab urbe est profectus. ad quinque milia uoluntariorum, Romani sociique, qui emerita stipendia sub imperatore P. Africano habebant, praesto fuere exeunti consuli et nomina dederunt. per eos dies, quibus est profectus ad bellum consul, ludis Apollinaribus, a. d. quintum idus Quinctiles caelo sereno interdiu obscurata lux est, cum luna sub orbem solis subisset. et L. Aemilius Regillus, cui naualis prouincia euenerat, eodem tempore profectus est. L. Aurunculeio negotium ab senatu datum est, ut triginta quinqueremes, uiginti triremes faceret, quia fama erat Antiochum post proelium nauale maiorem classem aliquanto reparare."

That is, "The consul Lucius Cornelius, having finished what was necessary to be done at Rome, gave public notice, in an assembly of the people, that the soldiers, whom he himself had enlisted for a reinforcement, and those who were in Bruttiurn with Aulus Cornelius, proprætor, should all meet him at Brundusium on the ides of July. ... About five thousand volunteers of the Romans and allies, who had served out their campaigns, under the command of Publius Africanus, attended the consul at his departure, and gave in their names. At the time in which the consul set out to the war during the celebration of the Apollinarian games, on the fifth day before the ides of July, though the sky was serene, the light was obscured in the middle of the day, when the moon passed beneath the orb of the sun. L. Æmilius Regillus, ... " [11]. Let us stress again that, at the time of Licius Cornelius (Asiaticus) consulship, the calendar was the roman calendar of Numa, and not the Julian Calendar of Augustus. Therefore, the Latin text tells that the eclipse was on $\boldsymbol{a}$. $d$. quintum idus Quinctiles, but the English translation gives it on the fifth day before the ides of July. Actually, it is common to find the date of this eclipse translated as 11 July (five days - inclusive count - before Ides of July).

Livy tells that the eclipse was interdiu, translated in the "middle of the day". However, interdiu means only during the day. In any case, let us remember this if we want to consider the local time of the eclipse.

Sir David Brewster is mentioning this Livy's eclipse in his item on "Chronology" in the Edinburgh Encyclopædia [12]. In a table concerning lunar and solar eclipses, we find that he wrote: "Sun, 190, 14th March. Scipio Asiaticus sets out for Africa". This is the astronomical date of the eclipse of 190 $\mathrm{BC}$, given in Julian proleptic calendar by Brewster (probably this date had been previously determined by other scholars). Let us stress that the calendar, used by astronomers, has not to be confused with the historical roman calendar of Julius Caesar and Augustus.

In the Livy's text, the year of the eclipse is fixed by the consulship of Lucius Cornelius Scipio Asiaticus. He served under his brother, Publius Cornelius Scipio Africanus, in Spain during the Second Punic War. He was curule aedile in 195 BC [13], and praetor assigned to Sicily in 193 BC. He became consul in 190 BC with co-consul Gaius Laelius. Accompanied by his brother as a legate, Africanus obtained the province of Greece and the command of the war against Antiochus. After the victory over Antiochus, in the occasion of his return to Rome, he celebrated a triumph (189 BC) and requested the title "Asiaticus".

In any case, we have that the historical date given by Livy, 11 Quintilis, is corresponding to the Julian date 14th March, 190 BC (see [6] for a discussion of Julian dates). The equivalence was used in [14], 
to determine the Julian Chronology of the Comitial Dates in Livy.

Is it possible that a so great difference existed between the astronomical (14th March) and the historical date (the fifth day before the ides of July, that is, 11 July)? Yes, according to [1].

Let us investigate the eclipse. We use CalSKI, with Rome as location. On 14 March 190 BC, as told by Brewster, we find a Partial Solar Eclipse, Saros-Number: 75. Obscuration=90.336\%. Altitude $=9.1^{\circ}$, Azimuth $=103.9^{\circ}$ ESE, Duration of eclipse $=1 \mathrm{~h} 59 \mathrm{~m}, \mathrm{ET}-\mathrm{UT}=12654.4 \mathrm{sec}$.

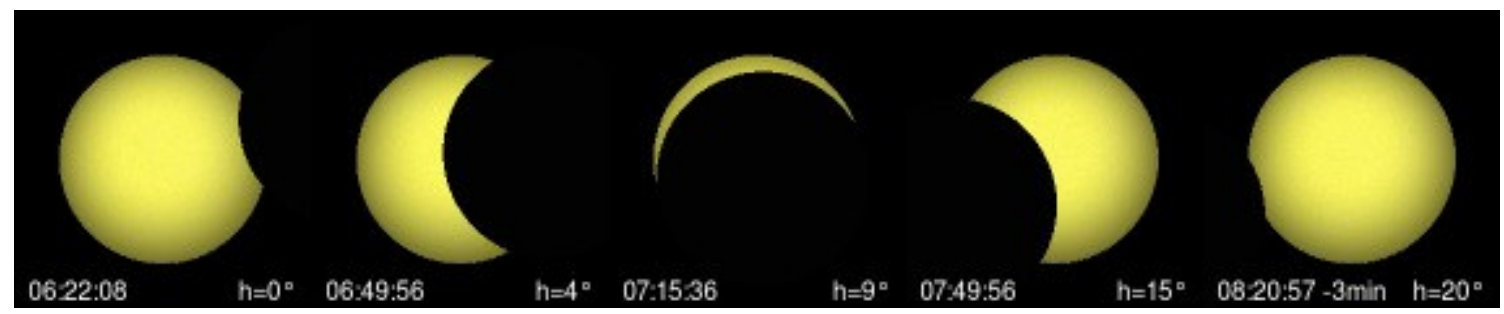

Figure 2: Courtesy CalSKY. Graphical chart of the partial eclipse of 190 BC seen from Rome.

Let us stress that the altitude of the sun was of $9.1^{\circ}$, that is, this eclipse occurred in the morning. As told before, Livy gives a specific date. The eclipse of $190 \mathrm{BC}$ was at the time of Ludis Apollinares, a. d. quintum idus Quinctiles. It means five days (inclusive count) before the Ides of Quintilis. The Quintilis is the month that became July, in the reform of the calendar decided by Augustus. Therefore, since we are accustomed to a solar calendar, we imagine July as the core of the summer. But, at the time, the Romans had a lunar calendar, organized in a peculiar way, requiring the adjustment by means of the intercalation of a month to have the calendar in agreement to seasons. For some reasons, in 190 $\mathrm{BC}$, the calendar shifted of four months.

If we analyse the partial eclipse of 14th March, $190 \mathrm{BC}$, we can see that it was before the spring equinox. How can we determine the spring equinox? Supposing that the ancient astronomers observed the sun rising perfectly on the cardinal East, we see by means of CalSKY, that on 22 March 190 BC, the sunrise azimuth on the astronomical horizon was of $90.6^{\circ}$, on 23 March $190 \mathrm{BC}$ of $90.1^{\circ}$, the 24 March $190 \mathrm{BC}$ of $89.6^{\circ}$. Therefore, the solar eclipse of $190 \mathrm{BC}$ was before the spring equinox about 23 or 24 of March.

Not properly managed, in $190 \mathrm{BC}$ the calendar turned out to be shifted of four months with respect to the astronomical time. In the case of the eclipse of $203 \mathrm{BC}$, if we use the date mentioned by Cicero, the shift of the calendar was of about one month.

\section{Ludi Apollinares}

So we have seen that the eclipse of $190 \mathrm{BC}$ was before the spring equinox and therefore that the Ludi were before it too. In [15], it is told that the Ludi were instituted at Rome during the second Punic war, four years after the battle of Cannae (212 BC). "It was stated, by some of the ancient annalists, that these ludi were instituted for the purpose of obtaining from Apollo the protection of human life during the hottest season of summer; but Livy and Macrobius adopt the account founded upon the most authentic document, the carmina Marciana themselves, that the Apollinarian games were instituted partly to obtain the aid of Apollo in expelling the Carthaginians from Italy, and partly to preserve, through the favour of the god, the republic from all dangers. The oracle suggested that the games should be held every year under the superintendence of the praetor urbanus, and that ten men should perform the sacrifices according to Greek rites. ... The games themselves were held in the Circus Maximus, the spectators were adorned with chaplets, and each citizen gave a contribution towards defraying the expenses (Festus, s.v. Apollinares). The Roman matrons performed supplications, the people took their meals in the propatulum with open doors, and the whole day for the festival lasted only one day - was filled up with ceremonies and various other rites. At this 
first celebration of the ludi Apollinares no decree was made respecting the annual repetition suggested by the oracle, so that in the first year they were simply ludi votivi or indictivi. The year after (B.C. 211) the senate, on the proposal of the praetor Calpurnius, decreed that they should be repeated, and that in future they should be vowed afresh every year (Liv. XXVI.23). The day on which they were held varied every year according to circumstances. A few years later, however (B.C. 208), when Rome and its vicinity were visited by a plague, the praetor urbanus, P. Licinius Varus, brought a bill before the people to ordain that the Apollinarian games should in future always be vowed and held on a certain day (dies status), viz. on the 6th of July, which day henceforward remained a dies sollemnis (Liv. XXVII.23). The games thus became votivi et stativi, and continued to be conducted by the praetor urbanus (Cic. Phil. II.13). But during the empire the day of these solemnities appears again to have been changed, for Julius Capitolinus (Maxim. et Balbin. c1) assigns them to the 26th of May."

In [16], we find other details. It is told that the Ludi "Si svolgevano annualmente per un periodo di otto giorni, precisamente dal 5 al 13 luglio, e solo l'ultimo giorno si svolgevano dentro il circo. Ma in origine i Ludi Apollinari non si svolgevano in una data fissa. A partire dalla fine del 211 a.C., il senato accolse la proposta del pretore Gaio Calpurnio Pisone e decretò che i ludi Apollinari diventassero stabilmente annuali. In seguito fu il pretore urbano Publio Licinio Varo a stabilire una data fissa per i Ludi. P. Licimius Varo praetor Urbis legem ferre ad populum jussus, ut hi ludi in perpettum in statam diem voverentur. Ipse primus ita vovit, fectique ante diem tertium nonas quintiles: is dies deinde solennis servatur [17]. Therefore, we have that the Ludi where from 5 July to 13 July (Quintilis). In [18], we read that the Ludi Apollinares were from 6th July to 13th July, i.e. eight days long. It is told that "Livy adds that the fixed day was the third day before the Nones of July, which is a slip for the third day before the Ides of July. Orginally held on July 13th, the Ludi Apollinares extended to eight days." Let us stress once more that the days of the Ludi had been fixed in the month of July, but that the month of July was moving its position from year to year.

\section{$188 \mathrm{BC}$}

As told in [1], Livy is mentioning another eclipse, the total eclipse of $188 \mathrm{BC}$.

Let us read in [19]: "De exercitibus ita placuit: ex Gallia legiones, quae sub C. Laelio fuerant, ad M. Tuccium propraetorem in Bruttios traduci, et, qui in Sicilia esset, dimitti exercitum, et classem, quae ibi esset, Romam reduceret M. Sempronius propraetor. Hispaniis singulae legiones, quae tum in iis prouinciis erant, decretae, et ut terna milia peditum, ducenos equites ambo praetores in supplementum sociis imperarent secumque transportarent. Priusquam in prouincias noui magistratus proficiscerentur, supplicatio triduum pro collegio decemuirorum imperata fuit in omnibus compitis, quod luce inter horam tertiam ferme et quartam tenebrae obortae fuerant. Et nouemdiale sacrificium indictum est, quod in Auentino lapidibus pluuisset."

[20]: "Respecting the armies, they passed the following resolutions - that the legions which had served under Caius Lælius, should be removed out of Gaul into Bruttium, to Marcus Tuccius, the proprætor; that the army which was in Sicily should be disbanded, and that Marcus Sempronius, the proprætor, should bring back to Rome the fleet that was there. For the Spains were decreed the legions then in those provinces, one for each, with orders, that each of the two prætors should levy from among the allies, as a reinforcement, three thousand foot and two hundred horse, and bring them with them. Before the new magistrates set out for their provinces, a supplication, of three days' continuance, was ordered by the college of decemvirs to be performed in every street, on account of a darkness having overspread the light of day, between the third and fourth hours; and the nine days' solemnity was proclaimed, because there had been a shower of stones on the Aventine."

By means of CalSKY we have the following. 17 July 188 BC: Total Solar Eclipse, Saros-Number: 62. Obscuration $=100.000 \%$. Azimuth $=74.8^{\circ}$ ENE, Duration of eclipse $=2 \mathrm{~h} 04 \mathrm{~m}$ Duration total phase $=0 \mathrm{~m} 43 \mathrm{~s}$, ET-UT $=12626.4 \mathrm{sec}$. 


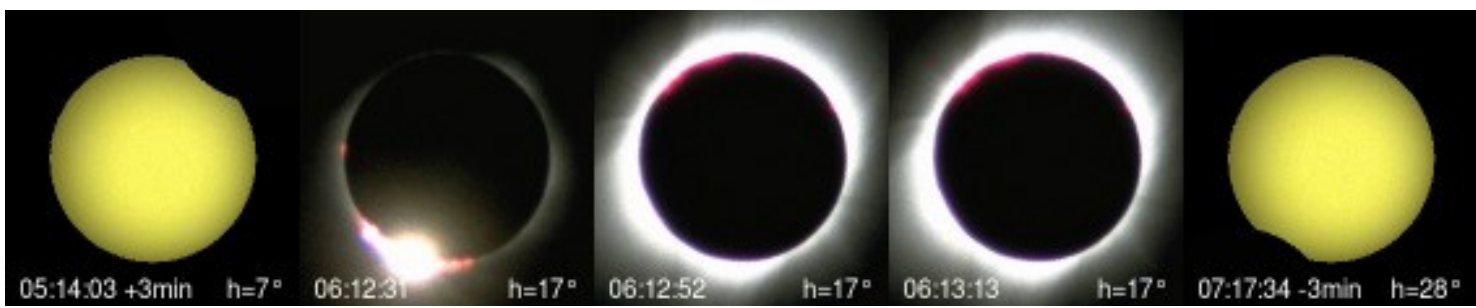

Figure 3: Courtesy CalSKY. Graphical chart of the total eclipse of 188 BC seen from Rome.

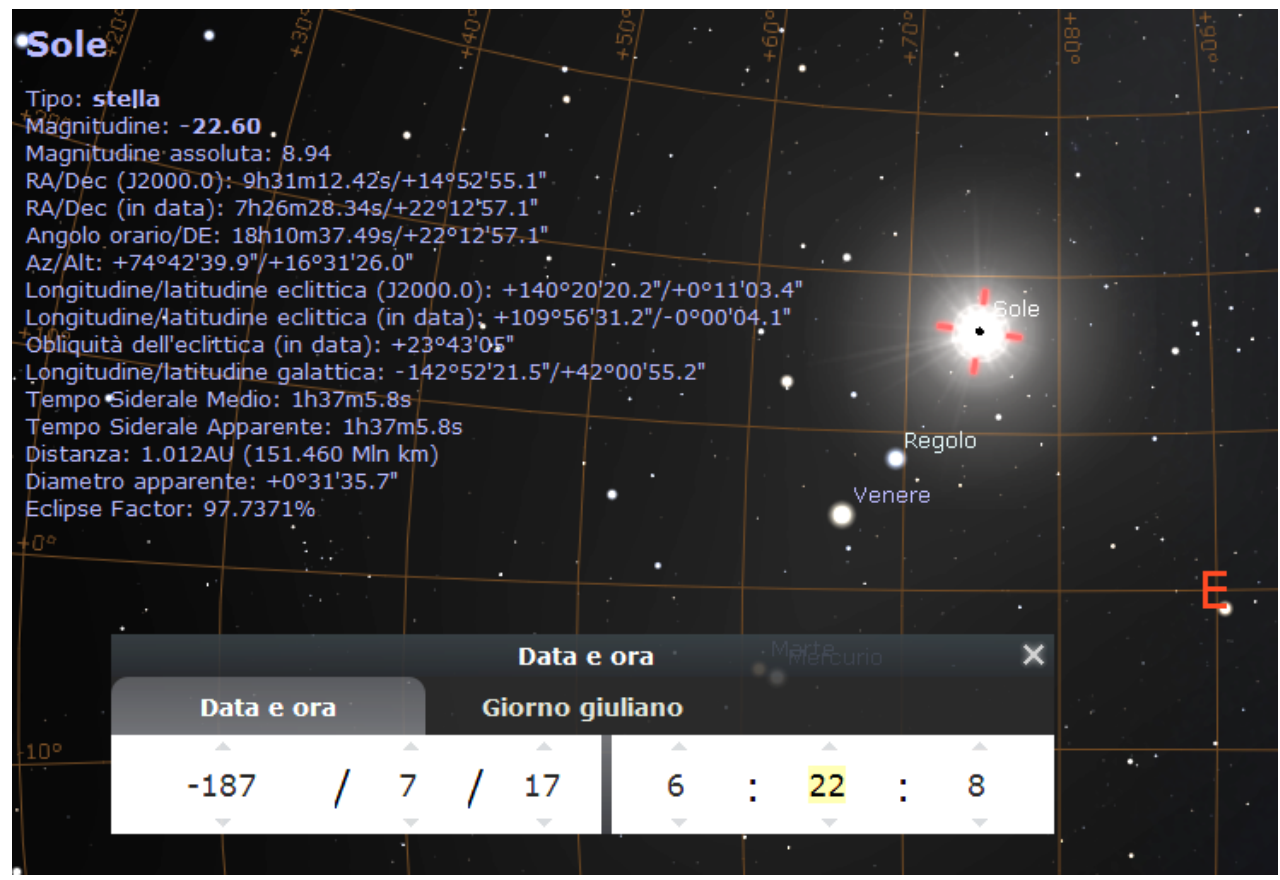

Figure 4: The same information about the eclipse of $188 \mathrm{BC}$ we can obtain using Stellarium software. Let us note that year $188 \mathrm{BC}$ is rendered in this software as -187 . The sun was higer in the sky, with respect to the eclipse of $190 \mathrm{BC}$.

\section{CalSky Map Interface}

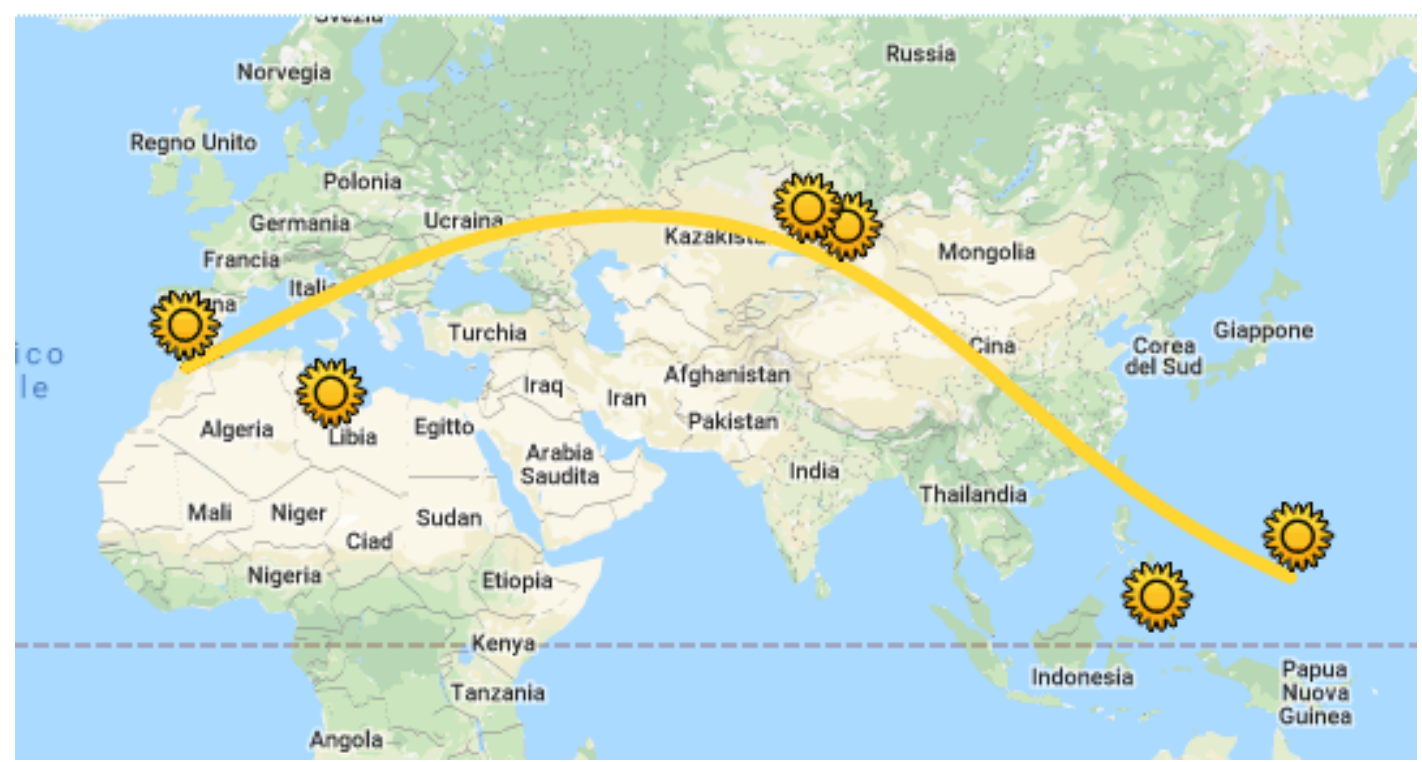

Figure 5: Thanks to CalSKY we can also see the path of the solar eclipse of $188 \mathrm{BC}$. 
Let us note that it seems that the partial eclipses of $187 \mathrm{BC}$ and $183 \mathrm{BC}$, visible from Rome, are not mentioned by Livy. 31 December 187 BC: Partial Solar Eclipse, Saros-Number: 77. Obscuration $=51.538 \%$. Altitude $=23.1^{\circ}$, Azimuth $=195.4^{\circ} \mathrm{SSW}$, Duration of eclipse $=3 \mathrm{~h} 14 \mathrm{~m}$, ETUT=12609.0sec. 19 October 183 BC: Partial Solar Eclipse, Saros-Number: 79. Obscuration $=63.575 \%$. Altitude $=37.2^{\circ}$, Azimuth $=160.5^{\circ}$ SSE, Duration of eclipse $=2 \mathrm{~h} 34 \mathrm{~m}$, ET$\mathrm{UT}=12563.8 \mathrm{sec}$.

As told by Livy, from Rome, the total eclipse on 17 July 188 BC was observed.

Let us use again CalSKY for the rising of the sun. From 23 June $188 \mathrm{BC}$ to 29 June $188 \mathrm{BC}$ we read that the northernmost sunrise azimuth was of $56.4^{\circ}$; we can conclude that the summer solstice was on 26 June $188 \mathrm{BC}$. The total eclipse of $188 \mathrm{BC}$ was after the summer solstice for sure.

Let us repeat what Livy is telling. "Before the new magistrates set out for their provinces, a supplication, of three days' continuance, was ordered by the college of decemvirs to be performed in every street, on account of a darkness having overspread the light of day, between the third and fourth hours; and the nine days' solemnity was proclaimed, because there had been a shower of stones on the Aventine." The eclipse happened when the "new" magistrates had been set out for provinces. However, when this happened in the Roman calendar?

\section{Lunar eclipse of $168 \mathrm{BC}$}

In [1] we read that the lunar eclipse of 21 June $168 \mathrm{BC}$ is reported in XLIV,37,5-9 at the date 3 September 168 BC "républicain". We are at the time of the Pydna Battle.

[21] "Castris permunitis C. Sulpicius Gallus, tribunus militum secundae legionis, qui praetor superiore anno fuerat, consulis permissu ad contionem militibus uocatis pronuntiauit, nocte proxima, ne quis id pro portento acciperet, ab hora secunda usque ad quartam horam noctis lunam defecturam esse. id quia naturali ordine statis temporibus fiat, et sciri ante et praedici posse. itaque quem ad modum, quia certi solis lunaeque et ortus et occasus sint, nunc pleno orbe, nunc senescentem exiguo cornu fulgere lunam non mirarentur, ita ne obscurari quidem, cum condatur umbra terrae, trahere in prodigium debere. nocte, quam pridie nonas Septembres insecuta est dies, edita hora luna cum defecisset, Romanis militibus Galli sapientia prope diuina uideri; Macedonas ut triste prodigium, occasum regni perniciemque gentis portendens, mouit nec aliter uates. clamor ululatusque in castris Macedonum fuit, donec luna in suam lucem emersit".

[22] "When the camp had been thoroughly fortified, Caius Sulpicius Gallus, a military tribune of the second legion, who had been prætor the year before, with the consul's permission collected the soldiers in assembly, and gave them notice, lest they should any of them consider the matter as a prodigy, that, "on the following night, the moon would be eclipsed, from the second hour to the fourth." He mentioned that, "as this happened in the course of nature, at stated times, it could be known, and foretold. As, therefore, they did not wonder at the regular rising and setting of the sun and moon, or at the moon's sometimes shining with a full orb, and sometimes in its wane, showing only small horns, so neither ought they to construe as a portent, its being obscured when covered with the shadow of the earth." When on the night preceding the day before the nones of September, at the hour mentioned, the eclipse took place, the Roman soldiers thought the wisdom of Gallus almost divine; but the Macedonians were shocked, as at a dismal prodigy, foreboding the fall of their kingdom and the ruin of their nation; nor did their soothsayers explain it otherwise."

Just before, Livy is telling that " (tempus) anni post circumactum solstitium erat; hora diei iam ad meridiem uergebat; iter multo puluere et incalescente sole factum erat. lassitudo et sitis iam sentiebatur et meridiem aestum magis accensurum cum mox adpareret, statuit sic adfectos recenti atque integro hosti non abicere; sed tantus ardor in animis ad dimicandum utcumque erat, ut consuli non minore arte ad suos eludendos quam ad hostes opus esset." The year was after the turn of the summer solstice; the time of the day was approaching towards noon; and his march had been performed amidst great quantities of dust, and the increasing heat of the sun. Lassitude and thirst were already felt, and both would certainly be aggravated by mid-day coming on. ... and so on. 
Let us use CalSKY on 21 June 168 BC. Total Lunar Eclipse. Saros-Number: 56, Magnitude=1.257, Position angle $=356.1^{\circ}$, Position angle vertex $=36.7^{\circ}$. Brightness $=-1.5 \mathrm{mag}$, Danjon scale $\mathrm{L}=2.5$ (deep red), Diameter $=29.86$. Duration total phase $=76.8$ minutes, Duration partial phase $=222.1$ minutes, Duration penumbral phase $=364.0$ minutes, ET-UT $=12391.2 \mathrm{sec}$. Altitude $=5.7^{\circ}$, Azimuth $=129.1^{\circ} \mathrm{SE}$, Sun altitude $=-6.7^{\circ}$.

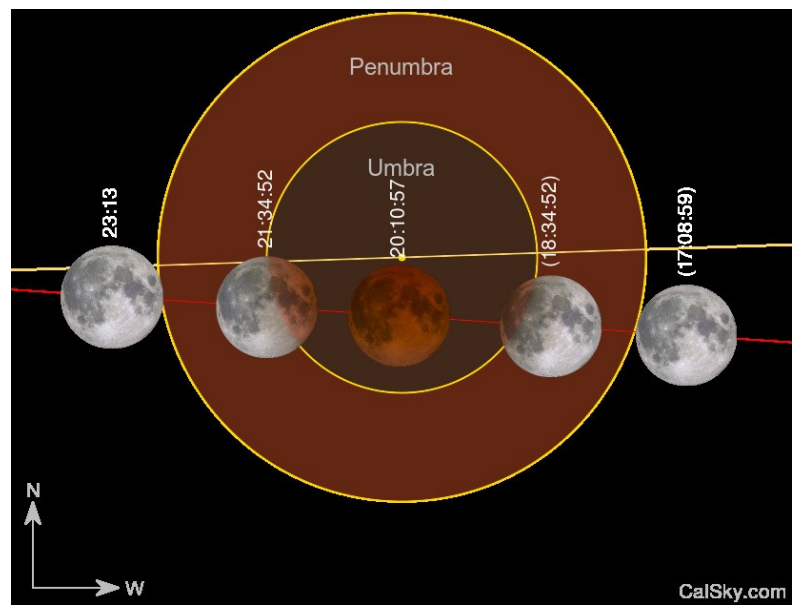

Figure 6: Courtesy CalSKY. Graphical chart of the eclipse seen from Kateríni (Greece), near the place of the Pydna Battle.

Let us try to find the summer solstice in the year $168 \mathrm{BC}$. By means of CalSKY we find the northernmost sunrise azimuths: 25 Jun 168BC Sunrise az $=57.4^{\circ}, 26$ Jun $168 \mathrm{BC}$ Sunrise az $=57.3^{\circ}$, 27 Jun 168BC Sunrise $a z=57.3^{\circ}, 28$ Jun $168 \mathrm{BC}$ Sunrise $\mathrm{az}=57.4^{\circ}$. Therefore, we see that the lunar eclipse was before the summer solstice, which was on 26 or 27 June. Livy is telling that the time was just after the summer solstice. Is it possible that the Latin text had been corrupted, and that, instead of "post" we have to read "ante"? The reason of a possible corruption could be the following. The date mentioned by Livy, the night between 3 and 4 September, in a historical Julian calendar is always after the summer solstice. Therefore, when copying the manuscript, a medieval amanuensis could have preferred changing "ante" in "post". However, let us stress that in the case of the republican calendar, in $168 \mathrm{BC}$, September 3 or 4 was before the summer solstice. As stressed by De Sanctis in his chronology of the Roman history [23], that the eclipse was after or before the solstice of a few days is not important for history.

In any case, we have that the calendar had a shift of about two months and ten days.

A curiosity: Sir David Brewster in [12] gives a different Julian date for the eclipse, the 28th June, then "after" the summer solstice.

Sun. 190,14 th March. Scipio Asiaticus sets out for Asia.

Moon. 168, 28th June, $\begin{gathered}\text { This eclipse happened in the same night in which Paulus Emilius conquered Perseus, } \\ \text { king of Macedon. }\end{gathered}$

\section{Eclipse of $217 \mathrm{BC}$}

This is an eclipse that we find in Livy but not mentioned in [1]. We find it reported by [24].

[25] "Augebant metum prodigia ex pluribus simul locis nuntiata: in Sicilia militibus aliquot spicula. in Sardinia autem in muro circumeunti uigilias equiti scipionem quem manu tenuerit arsisse et litora crebris ignibus fulsisse et scuta duo sanguine sudasse, et milites quosdam ictos fulminibus et solis orbem minui uisum, et Praeneste ardentes lapides caelo cecidisse, et Arpis parmas in caelo uisas pugnantemque cum luna solem, et Capenae duas interdiu lunas ortas, et aquas Caeretes sanguine mixtas fluxisse fontemque ipsum Herculis cruentis manasse respersum maculis, et in Antiati metentibus cruentas in corbem spicas cecidisse, et Faleriis caelum findi uelut magno hiatu uisum quaque patuerit ingens lumen effulsisse; sortes sua sponte attenuatas unamque excidisse ita scriptam: 
"Mauors telum suum concutit", et per idem tempus Romae signum Martis Appia uia ac simulacra luporum sudasse, et Capuae speciem caeli ardentis fuisse lunaeque inter imbrem cadentis. Inde minoribus etiam dictu prodigiis fides habita: capras lanatas quibusdam factas, et gallinam in marem, gallum in feminam sese uertisse. His, sicut erant nuntiata, expositis auctoribusque in curiam introductis consul de religione patres consuluit. "

[26] Prodigies announced from many places at the same time, augmented the terror: in Sicily, that several darts belonging to the soldiers had taken fire; and in Sardinia, that the staff of a horseman, who was going his rounds upon a wall, took fire as he held it in his hand; that the shores had blazed with frequent fires; that two shields had sweated blood, at Praeneste that red-hot stones had fallen from the heavens, at Arpi that shields were seen in the heavens, and the sun fighting with the moon, at Capena that two moons rose in the day-time; that the waters of Caere had flowed mixed with blood; and that even the fountain of Hercules had flowed sprinkled with spots of blood. In the territory of Antium, that bloody ears of corn had fallen into the basket as they were reaping. At Falerii, that the heavens appeared cleft as if with a great chasm; and, that where it had opened, a vast light had shone forth; that the prophetic tablets had spontaneously become less; and that one had fallen out thus inscribed, "Mars shakes his spear." During the same time, that the statue of Mars at Rome, on the Appian way, had sweated at the sight of images of wolves. At Capua that there had been the appearance of the heavens being on fire, and of the moon as falling amidst rain. After these, credence was given to prodigies of less magnitude: that the goats of certain persons had borne wool; that a hen had changed herself into a cock; and a cock into a hen: these things having been laid before the senate as reported, the authors being conducted into the senate-house, the consul took the sense of the fathers on religious affairs.

This is the book concerning years BC 217-216. [26] "Hannibal, after an uninterrupted march of four days and three nights, arrives in Etruria, through the marshes, in which he lost an eye. Caius Flaminius, the consul, an inconsiderate man, having gone forth in opposition to the omens, dug up the standards which could not otherwise be raised...". We arrive at the Battle of Trasimene.

One of the omens was the eclipse seen in Arpi, near Foggia. So let us use CalSKY for that location. We have the following eclipse. 11 February 217 BC: Partial Solar Eclipse, Saros-Number: 56, Obscuration $=60.995 \%$, Altitude $=8.8^{\circ}$, Azimuth $=240.6^{\circ} \mathrm{WSW}$, Duration of eclipse $=2 \mathrm{~h} 00 \mathrm{~m}$, ET$\mathrm{UT}=12984.8 \mathrm{sec}$.

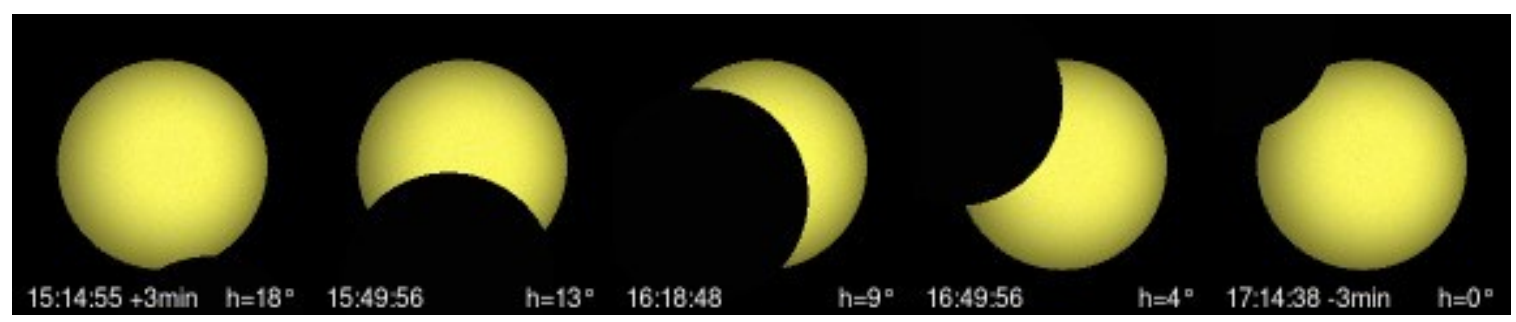

Figure 7: Courtesy CalSKY. Graphical chart of the partial eclipse of 217 BC seen from Arpi.

The partial eclipse was visible from Rome too, with a graphical chart like that in the Figure 7. Cloud skies in Rome? In any case, we have not a historical date.

\section{Conclusion}

Let us repeat the question given above, for the eclipse of $190 \mathrm{BC}$. Is it possible that a so great difference existed between the astronomical (14th March) and the historical date (fifth day before the ides of July, that is, 11 July)? Yes, it is possible because of the intrinsic method used to upgrade the lunar calendar. As told in [23], and discussed in [26], Livy did not make mistakes in reporting the dates. In any case, as we can see in [1], several scholars have discussed the Roman chronology, being almost unanimously in agreement with the chronology given in [1] and [23]. 


\section{References}

[1] Notes de Chronologie Romaine. Albert Deman and Marie-Thérèse Raepsaet-Charlier. Historia: Zeitschrift für Alte Geschichte. Bd. 23, H. 3 (3rd Qtr., 1974), pp. 271-296 (26 pages)

[2] Henry G Liddell, 1909, A History of Rome, John Murray, London, p. 29

[3] https://en.wikipedia.org/wiki/Mercedonius\#cite_note-6 (July, 10, 2019)

[4] https://la.wikisource.org/wiki/Ab_Urbe_Condita/liber_XXX

[5] https://www.gutenberg.org/files/12582/12582-h/12582-h.htm\#d38

[6] Sparavigna, Amelia Carolina. (2019, May 16). The first Calends of the Julian Calendar. Zenodo. http://doi.org/10.5281/zenodo.2860135

[7] Sparavigna, Amelia Carolina. (2019). On Dating the Lunar Eclipse of Alexander and the Battle of Gaugamela: Discussion of Evidence and Use of Archaeoastronomy for Chronology. Zenodo. http://doi.org/10.5281/zenodo.3263733

[8] https://la.wikisource.org/wiki/Ab_Urbe Condita/liber_XXXVII

[9] web.archive.org/web/20190709070122/https://a.wikisource.org/wiki/Ab_Urbe_Condita/liber XXXVII

[10] Paolo Bonavoglia, Eclissi dell'antichità - Fonti antiche - L'eclissi di Sole a Roma 14 marzo 189. https://web.archive.org/web/20190709070323/http://astro.bonavoglia.eu/fonti/livio-189.html

[11] https://www.gutenberg.org/files/44318/44318-h/44318-h.htm\#a4

[12] https://archive.org/details/edinburghencyclo06edinuoft/page/414

[13] T. Robert S. Broughton, The Magistrates of the Roman Republic, American Philological Association, 1952-1960. vol. 1 pg. 340.

[14] Bennett, C. (2004). Livy and the" Lex Hortensia": The Julian Chronology of the Comitial Dates in Livy. Zeitschrift für Papyrologie und Epigraphik, 165-176.

[15] Ludi Apollinares, Article by Leonhard Schmitz, on p715 of William Smith, A Dictionary of Greek and Roman Antiquities, John Murray, London, 1875.

http://penelope.uchicago.edu/Thayer/E/Roman/Texts/secondary/SMIGRA*/Ludi_Apollinares.html [16] https://it.wikipedia.org/wiki/Ludi_Apollinari

[17] Titus Livius Patavinus Ad codices parisinos recensitus, cum varietate lectionum et selectis commentariis. Item supplementa J. Freinshemil, curante N. E. Lemaire, Volume 5. 1823. Page 275.

[18] A Companion to Latin Studies, Edited bu Sir John Edwin Sandys. Cambridge University Press, 1910. Pag.505. https://archive.org/details/companiontolatin00sand/page/504

[19] https://la.wikisource.org/wiki/Ab_Urbe_Condita/liber_XXXVIII

[20] https://www.gutenberg.org/files/44318/44318-h/44318-h.htm\#b36

[21] https://la.wikisource.org/wiki/Ab_Urbe_Condita/liber_XLIV

[22] https://www.gutenberg.org/files/44318/44318-h/44318-h.htm\#h37

[23] Gaetano De Sanctis. Storia dei Romani, 1907. Milano, Bocca. Available at the page https://archive.org/details/storiadeiromani41 sanc/page/372

[24] https://web.archive.org/web/20161104064839/hbar.phys.msu.su/gorm/atext/ginzele0.htm

[25] https://la.wikisource.org/wiki/Ab_Urbe_Condita/liber_XXII

[26] https://www.gutenberg.org/files/10907/10907-h/10907-h.htm\#d1

[27] Meloni, P. (1954). Ancora sul Calendario romano nell' anno della battaglia di Pidna (168 a. Cr.).

Latomus. T. 13, Fasc. 4 (Octobre-Decembre 1954), pp. 553-568 (16 pages) 